\title{
Cochleosaccular degeneration-cataract syndrome
}

INSERM

\section{Source}

INSERM. (1999). Orphanet: an online rare disease and orphan drug data base.

Cochleosaccular degeneration-cataract syndrome. ORPHA:3233

Cochleosaccular degeneration-cataract syndrome is characterised by progressive sensorineural hearing loss due to severe cochleosaccular degeneration and cataract. So far, it has been reported in two families. Transmission is autosomal dominant. 